\title{
Implementasi teori tangga dan teori jalan dalam memberikan paham penalaran perkalian matematika kelas II MI Al-hasan Cipari
}

\author{
Malihatul 'azizah', Muhamad Fatih Lutfan', Laely Fauziah ${ }^{3}$, Arinal Farihah ${ }^{4}$ \\ Program Studi Pendidikan Guru Madrasah Ibtidaiyah, STAI Miftahul Huda Al Azhar Banjar \\ pgmikotabanjar4@gmail.com
}

\begin{abstract}
ABSTRAK
Pembelajaran matematika memerlukan pemahaman yang mendalam tentang bagaimana bisa memberikan pemahaman kepada anak didik sehingga anak didik mampu membangun pemikirannya sesuai usianya. Tujuan dari penelitian untuk mengetahui bagaimana seorang Guru dalam melaksanakan pembelajaran matematika pada tingkat Sekolah Dasar atau MI, agar pembelajaran dapat terlaksana dengan baik. Metode yang digunakan dalam penelitian ini adalah deskriptif kualitatif, subyek dalam penelitian ini adalah pendidik matematika MI, kepala sekolah, dan anak didik kelas II MI Al-Hasan Mulyadadi Cipari. Teknik pengumpulan data yang dilakukan adalah pengamatan yang dilakukan di dalam kelas II dan lingkungan sekitar; meliputi proses pembelajaran matematika di MI Al-Hasan Mulyadadi Cipari. Teknik pengumpulan data lainnya observasi, wawancara dan dokumentasi. Data diolah menggunakan triangulasi Data. Hasil penelitian ini menunjukan pembelajaran matematika menggunakan teori jalan dan teori tangga telah dilakasanakan. Pada pelaksanaannya teori jalan bisa dilakukan dengan membuat tabel perkalian; mendesain pembelajaran dengan menekankan hafalan dan pemahaman kepada angka sehingga tidak terjadi pengulangan; teori tangga pengulangan kembali jika teori/materi sebelumnya ada yang belum dipahami oleh anak didik. Setelah melakukan teori tangga Guru melakukan evaluasi dengan tanya jawab setiap harinya dan menekankan pada nilai angka perkalian yang sulit untuk dihafalkan oleh anak didik.
\end{abstract}

Kata Kunci: Pembelajaran matematika, teori jalan, teori tangga.

Implementation of household theory and the road theory in providing reasons for the review of mathematical class II MI Al-hasan Cipari

\begin{abstract}
Mathematical learning requires a deep understanding of how to provide understanding to students so that students are able to develop Learning mathematics requires a deep understanding of how to provide understanding to students so that students are able to build their thoughts according to their age. The purpose of this research is to find out how a teacher in carrying out mathematics learning at the elementary school or MI level, so that learning can be carried out well. The method used in this research is descriptive qualitative, subjects in this study are MI mathematics educators, school principals, and grade II students of MI Al-Hasan Mulyadadi Cipari. Data collection techniques carried out were observations made in class II and the surrounding environment; includes the process of learning mathematics at MI Al-Hasan Mulyadadi Cipari. Other data collection techniques are observation, interview and documentation. Data is processed using data triangulation. The results of this study indicate mathematics learning using road theory and ladder theory has been carried out. In the implementation of road theory can be done by making multiplication tables; design learning by emphasizing rote learning and understanding of numbers so that repetition does not occur; repetition ladder theory if there is a theory / material beforehand that is not yet understood by students. After doing the theory ladder Teacher evaluates with questions and answers every day and emphasizes the value of multiplication numbers that are difficult for students to memorize.
\end{abstract}

Keywords: Mathematical learning, pathway theory, ladder theory 


\section{PENDAHULUAN}

Kemampuan seorang pendidik dalam merencanakan kegiatan pembelajaran merupakan salah satu faktor penentu keberhasilan bagi peserta didik dalam melaksanakan proses belajar mengajar. karena seorang guru adalah seorang pengajar, turor, konselor dan motivator bagi peserta didiknya, dimana guru berperan sebagai orang yang mengarahkan kegiatan pembelajaran di dalam kelas agar bisa mendapatkan hasil yang maksimal. Untuk mengetahui berhasil atau tidaknya pembelajaran yang dilaksanakan, seorang guru akan melakukan kegiatan evalusi yaitu dengan test baik secara lisan maupun tulisan.

Pembelajaran matematika merupakan pembelajaran yang perlu mendapatkan perhatian khusus, karena matematika memiliki objek dasar dan abstrak. Pembelajaran Matematika adalah suatu proses belajar mengajar yang dibangun oleh guru untuk mengembangkan kreativitas berpikir anak didik yang dapat meningkatkan kemampuan mengkonstruksi pengetahuan baru, sebagai upaya peningkatan penguasaan yang baik terhadap matematika (Amir \& Risnawati, 2016, p. 8).

Menurut Hans Freudental matematika merupakan aktivitas insani dan harus dikaitkan dengan realitas, dengan demikian matematika merupakan cara berpikir logis yang dipresentasikan dalam bilangan ruang dan bentuk dengan aturan yang telah ditentukan. Dalam proses mengajarkan matematika pada tingkat anak didik usia sekolah dasar harus menyiapkan metode yang mampu mengembangkan proses berpikir anak didik, menurutnya matematika merupakan proses penalaran, yang utama bukan pada rumus tetapi bagaimana mengajak anak didik untuk berusaha memberikan penalaran dengan pola keseimbangan. ${ }^{1}$

${ }^{1}$ Wawancara dengan Hanipudin, S.H. Guru Matematika di MI Al-Hasan Mulyadadi, tanggal 15 Februari 2020 


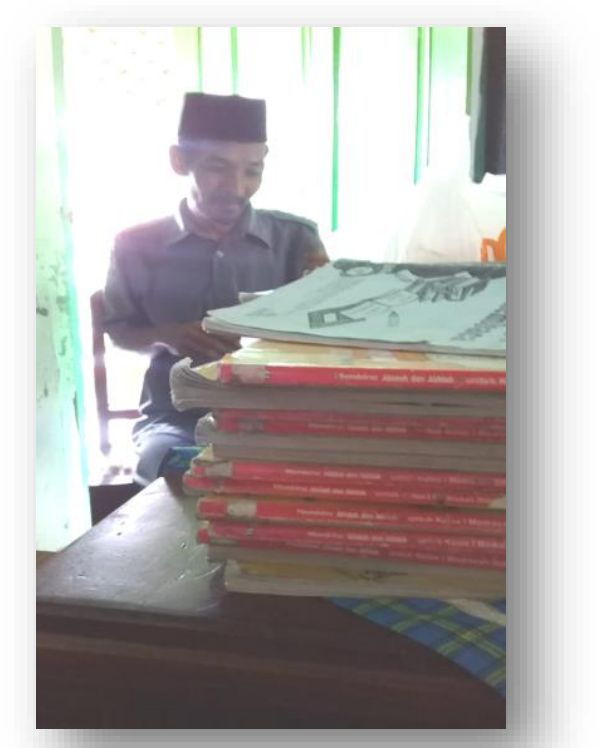

Sumber : Dokumentasi Penelitian, 2020

\section{Gambar 1.1 Wawancara dengan pak Hanif Guru Matematika di MI Al-Hasan}

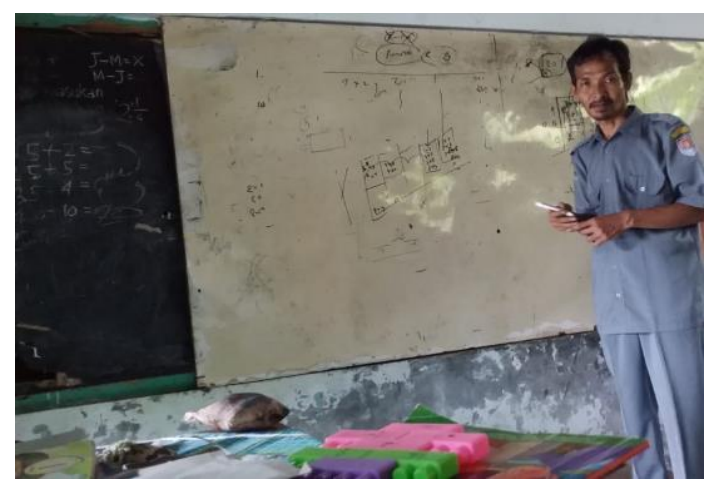

Sumber : Dokumentasi Penelitian, 2020

Gambar 1.2. Ilustrasi pelaksanaan pembelajaran di kelas

Gambar hanya ilustrasi karena sedang ada wabah covid 19 sehingga sekolah diliburkan

Kajian tentang tujuan dan fungsi pendidikan harus senantiasa dikaitkan dengan pendidikan dasar, karena sekolah dasar merupakan bagian dari sistem (sub ordinasi) pendidikan. Secara teknis pendidikan SD/MI dapat pula didefinisikan sebagai proses membimbing, mengajar dan melatih anak didik yang berusia 6-13 tahun untuk memiliki kemampuan dasar intelektual, sosial an personal yang terintegrasi dan sesuai dengan karakteristik perkembangannya. ('Azizah, 2018).

Proses berfikir dan cara belajar anak didik dalam pembelajaran matematika pada tingkat dasar $(1,2,3)$ dan kelas tinggi $(4,5,6)$ memiliki berapa perbebedaan, sehingga dengan demikian penelitian ini difokuskan pada pembahasan metode yang digunakan dalam kelas 2 dimana Guru/Pendidik menggunakan metode teori tangga dan teori jalan dalam meningkatkan kemampuan berpikir anak didik. 
Ada ketertarikan Penulis dalam penelitian ini, dimana MI Al-Hasan Mulyadadi Cipari selama beberapa periode mendapatkan Nilai Ujian Nasional pada mata pelajaran matematika, yaitu pernah menjadi lulusan terbaik 6 kali tingkat daerah, dan 2 kali tingkat kecamatan. Dengan latar belakang di atas penulis tertarik dengan Implementasi pembelajaran matematika yang digunakan oleh Guru matematika di MI Al-Hasan Mulyadadi Cipari, karena peningkatan kulitas pembelajaran yang dilaksanakan mengalami kemajuan terutama dalam pelajaran matematika. Maka dari itu, dalam penelitian ini Penulis akan membahas tentang penelitian yang berjudul "Implementasi Teori Tangga dan Teori Jalan dalam Memberikan Paham Penalaran Perkalian Matematika Kelas II MI Al-Hasan Mulyadadi Cipari”.

Berdasarkan latar belakang di atas maka dapat dirumuskan masalah sebagai berikut: (1) Bagaimanakah proses pembelajaran matematika pada materi perkalian dengan teori tangga dan teori jalan pada siswa kelas II MI Al-Hasan Mulyadadi Cipari ? (2) Bagaimana efektivitas pembelajaran matematika pada materi perkalian dengan teori tangga dan teori jalan pada siswa kelas II MI Al-Hasan Mulyadadi Cipari ?.

\section{METODE PENELITIAN}

Penelitian ini diklasifikasikan sebagai penelitian lapangan (Field Research) yaitu penelitian yang cara mengumpulan datanya langsung dari lapangan, dan penelitian ini dilakukan di lingkungan pendidikan sekolah dasar/MI. Jenis penelitian ini adalah penelitian kualitatif deskriptif. Subyek Penelitian, Subyek penelitian yang dalam memberikan informasi dalam penelitian. Adapaun subyek dalam penelitian ini adalah: Pendidik Matematika MI kelas II, Kepala Sekolah, dan Anak didik kelas II MI Al-Hasan Mulyadadi Cipari.

Teknik pengumpulan data menggunakan beberapa metode diantaranya Pertama, Metode observasi, Pengamatan dilakukan di dalam kelas II dan lingkungan sekitar meliputi proses pemeblajaran Matematika yang ada di kelas II MI Al-Hasan Mulyadadi Cipari. Kedua, Metode interview, Wawancara dilakukan kepada pihak pihak terkait yang dapat memberi informasi mengenai metode Pembelajaran Matematika kelas II MI Al-Hasan Mulyadadi Cipari, diantara kepala Sekolah yang dapat memberikan informasi mengenai keseluruhan data yang bersifat umum yang berhubungan dengan lembaga pendidikan setempat, dan pendidik Matematika informan kedua yang lebih mengetahui tentang proses belajar mengajar Matematika MI, kondisi anak didik serta sarana dan prasarana yang mendukung proses kegiatan belajar mengajar tersebut. Ketiga, Metode dokumentasi, dalam pelaksanaannya berguna untuk mengetahui proses pembelajaran Matematika secara langsung, yaitu dengan dokumentasi mengambil gambar/foto ketika pelaksanaan pembelajan Matematika. 
Teknik analisis data menggunakan dalam penelitian ini adalah teknik triangulasi yaitu teknik pemeriksaan keabsahan data yang memanfaatkan sesuatu yang lain diluar data itu untuk keperluan pengecekan atau sebagai pembanding data. Triangulasi pada penelitian ini memastikan terhimpunnya catatan setiap harinya dari wawancara dan observasi tersebut. Kemudian dilakukan uji silang terhadap materi catatan catatan harian tersebutuntuk memastikan tidak ada informasi yang bertentangan antara catatan harian wawancara dan observasi. Setelah itu hasil yang diperoleh diuji lagi dengan informan informan sebelumnya. Apabila terdapat perbedaan tersebut sampai peneliti menemukan sumber perbedaan dan materi perbedaaannya kemudian dilakukan konfirmasi dengan informan dan sumber sumber lain. Proses ini dilakukan terus menerus sepanjang proses pengumpulan data dan analisis data sampai diyakini tidak ada lagi perbedaan perbedaan dan tidak ada lagi yang dikonfirmasikan kepada informan.

\section{HASIL DAN PEMBAHASAN}

Pembelajaran erat kaitannya dengan membangun motivasi siswa agar ada kemauan semangat belajar yang tinggi. Adapun kriteria yang harus dimiliki oleh seorang pendidik untuk bisa menumbuhkan motivasi anak didik adalah 1). Mengenal karakteristik peserta didik, 2). Menguasai teori-teori belajar dan prinsipprinsip pembelajaran yang mendidik 3). Pengembangan kurikulum, 4). melaksanakan Kegiatan pembelajaran yang mendidik, 5) Memahami dan mengembangkan potensi, 6) Komunikasi dengan peserta didik, melaksanakan Penilaian dan Evaluasi 7) Bertindak sesuai norma agama, hukum, sosial dan kebudayaan nasional 8) Menunjukan pribadi yang dewasa dan teladan 9) Etos kerja, 10) tanggungjawab yang tinggi dan bangga menjadi guru, 11) Bersikap inkulsif, bertindak objektif dan tidak diskriminatif 12). Komunikasi dengan sesama guru, orang tua, peserta didik dan masyarakat. 13). Penguasaan materi struktur kosep dan pola pikir keilmuan yang mendukung, 14.) Mengembangkan keprofesian melalui tindakan reflektif(Mahardika, 2019).

Proses mengajarkan matematika di tingkat MI/SD Harus mempertimbangkan kemampuan anak usia sekolah dasar, yaitu pada masalah berhitung yang termasuk kemampuan dasar yang harus dimiliki oleh seseorang untuk bisa melaksanakan kehidupan dengan management yang baik. Sebagaimana tertulis pada NCTM (1989) bahwa pembelajaran matematika pada tingkat awal di sekolah dasar harus merujuk pada empat kompetensi yang memuat konsep bilangan dan juga kemampuan berhitung siswa, keempat kompetensi tersebut yakni: (1) Mengkonstruksi bilangan melalui pengalaman yang dilalui atau dengan menggunakan benda konkrit. (2) Memahami sistem bilangan dengan cara melakukan operasi hitung, pengelompokkan bilangan dan konsep nilai tempat. (3) Mengembangkan "number sense" dalam diri siswa. (4) Menjelaskan berbagai jenis penggunaan bilangan dalam kehidupan sehari-hari Berdasarkan 
penjelasan tersebut bahwa bilangan bagi siswa di tingkat MI perlu diajarkan dengan cara yang real.(Gelar Dwirahayu \& Nursida, 2016).

Teori tangga disini merupakan strategi yang digunakan pendidik dalam mengajarkan matematika pada materi perkalian kelas II MI Al-Hasan Mulyadadi Cipari. Teori tangga ini diartikan sebagai penyempurnaan pemahaman anak didik terhadap materi yang diajarkan, yaitu ketika anak belum bisa mehamai materi yang diajarkan dengan baik, Guru/Pendidik membuat strategi dengan menghadirkan tabel yang didesain sendiri dan dikolaborasikan dengan permainan sehingga terlihat seperti nyata. Pendidik menghadirkan suatu tabel yang menjelaskan angka-angka yang diinput pada tabel berupa tangga dari yang termudah sampai yang tersulit. Dalam teori ini berdasar pada pemahaman awal yang harus dibangun kepada Peserta didik, Karena pada hakikatnya ketika seseorang sudah memahami dasarnya pasti akan lebih mudah dalam memahami materi selanjutnya, begitupun sebaliknya untuk mengukur kemampuan anak didik jika materi dasar tidak dipahami dengan baik maka akan mengalami kesulitan pada materi berikutnya karena matematika adalah penalaran yang saling berhubungan satu dengan yang lainnya. Hal ini senada dengan hierarki pembelajaran matematika pengetahuan apa yang lebih dahulu harus dikuasai anak didik agar anak didik berhasil dalam mempelajari sesuatu yang baru, seperti apa yang dijelaskan oleh Resnick dan Ford dalam (Amir \& Risnawati, 2016, p. 10) berikut ini:

A bierarchy generated by considering the target task and asking "what whould (this child) have to know and how to do in order to perform this task.. ? karena itu bierarki belajar menurut Gagne harus disusun dari atas ke bawah atau top Down

Pernyataan Gagne berarti anak didik harus menguasai kemampuan prasyarat sebagai upaya keberhasilan anak didik dalam memhamai materi dan pengetahuan selanjutnya.Teori pembelajaran matematika menurut Burner bahwa belajar matematika adalah belajar tentang konsep dan struktur serta mencari hubungan antara konsep-konsep dan struktur struktur tersebut, menurut bruner, pemahaman atas suatu konsep beserta strukturnya menjadikan materi itu lebih mudah diingat dan dipahami lebih komprehensip (Hudojo, 2003, p. 61). Sedangkan menurut Ausubel Noval dan Hanesian menggolongkan belajar atas dua jenis, yaitu menghafal dan belajar bermakna. Menghafal mengacu pada menghafal pada suatu fakta atau hubungan seperti tabel dan lambang lambang atom atau kimia (Suparno, 1997, p. 53).

Pembelajaran matematika di sekolah dasar memiliki harapan dan tujuan: 1) anak anak belajar menikmati matematika, 2) anak anak belajar matematika penting, 3) anak anak melihat matematika sebagai sesuatu yang dibicarakan, dikomunikasikan dan bekerja sam adalam menyelesaikan masalah (Muhammad, 2017).

Pelaksanaan pembelajaran materi matematika didasarkan pada 4 pilar utama yaitu penambahan, pengurangan perkalian dan pembagian, dan kunci dari pemahaman anak didik adalah ketika menguasai 4 
pilar tersebut sebelum mulai pada pemahaman materi berikutnya. Pelajaran matematika diberikan kepadamu di SD dan MI untuk melatih kamu berpikir sistematis (teratur), logis (masuk akal), kritis (banyak bertanya; tak lekas percaya), kreatif (berdaya cipta), dan konsisten (ajek; taat aturan). Hal ini dilakukan, antara lain, melalui pelatihan penambahan, pengurangan, pembagian, dan perkalian bilangan.(Fajriah \& Triawati, 2008, p. III).

Dalam pelaksaaan pembelajaran matematika kelas II MI Al-Hasan pada materi perkalian, pendidik menerapkan Strategi teori tangga yang kemudian diikuti oleh teori jalan, untuk melengkapi kegiatan pembelajaran matematika sesuai dengan pilar pembelajaran matematika yang sistematis dan kreatif. Maksud teori jalan disini adalah bagaimana memberikan pemahaman kepada anak didik untuk bisa memahami proses jalannya pada materi matematika, misal ketika mengajarkan perkalian, karena ada yang harus ditekankan pada pembelajaran matematika, yaitu tidak hanya hapal tetapi paham, contoh kecilnya, ketika seseorang paham dengan isi letak rumah seseorang maka dia tidak perlu lagi berpikir ketika akan menuju kamar mandi, kamar tidur dan lain sebagainya, apabila orang tersebut masih berpikir letak kamar sendiri dimana? sepertinya harus melewati dapur dahulu baru belok kanan, itu tandanya seseorang tersebut belum memahami ruamah tersebut, begitu pula dengan matematika, ketika seorang anak ditanya $7 \times 8$ berapa? dan respon anak didik masih harus berpikir lama, berarti anak didik tersebut belum sampai pada teori jalan. Karena pada hakikatnya taori jalan itu lahir dari teori pemahaman yang awalnya dari mengingat dan menghapal yang berada pada tingkat berpikir paling dasar untuk menuju tingkat berpikir analisis. Pada pelaksanaannya, teori jalan bisa dilakukan dengan: Menekankan pada proses jalannya pemahaman seorang anak didik untuk belajar lebih bermakna, mengikuti perkembangan kognitif anak didik, yang kemudian dicarikan jalan termudah dalam memahami materi.

Cara termudah yang dilakukan oleh guru matematika di MI Al-Hasan Mulyadadi Cipari pada materi perkalian yaitu, pertama adalah membuat tabel yang berisi angka angka yang tidak pada umumnya, biasanya pada perkalian 1-10 satu tabel full, dalam konsep teori jalan di sini langsung perkalian 2-9. Karena menurut bapak Hanipudin, ${ }^{2}$ 1x1 sampai seterusnya tidak perlu dihapal karena jumlahnya sangat mudah diketahui, sama seperti perkalian 10 jadi tabel perkalian langsung dikhususkan pada perkalian 2-9. Adapaun keuntungan yang bisa didapatkan adalah: anak didik tidak merasa terbebani dengan angka yang banyak dan hanya diulang ulang sehingga akan mengacau pikiran anak didik, dan anak didik menjadi tidak fokus. Adapun desain tabel pada teori jalan adalah sebagai berikut:

Pertama, mendesain pembelajaran dengan menekankan hapalan dan pemahaman kepada angka yang tidak perlu diualang ulang. Pada perkalian kita lihat tabel di bawah ini:

${ }^{2}$ Laporan Wawancara (Hanipudin, S.H. 202015 Februari) Personal Interview 


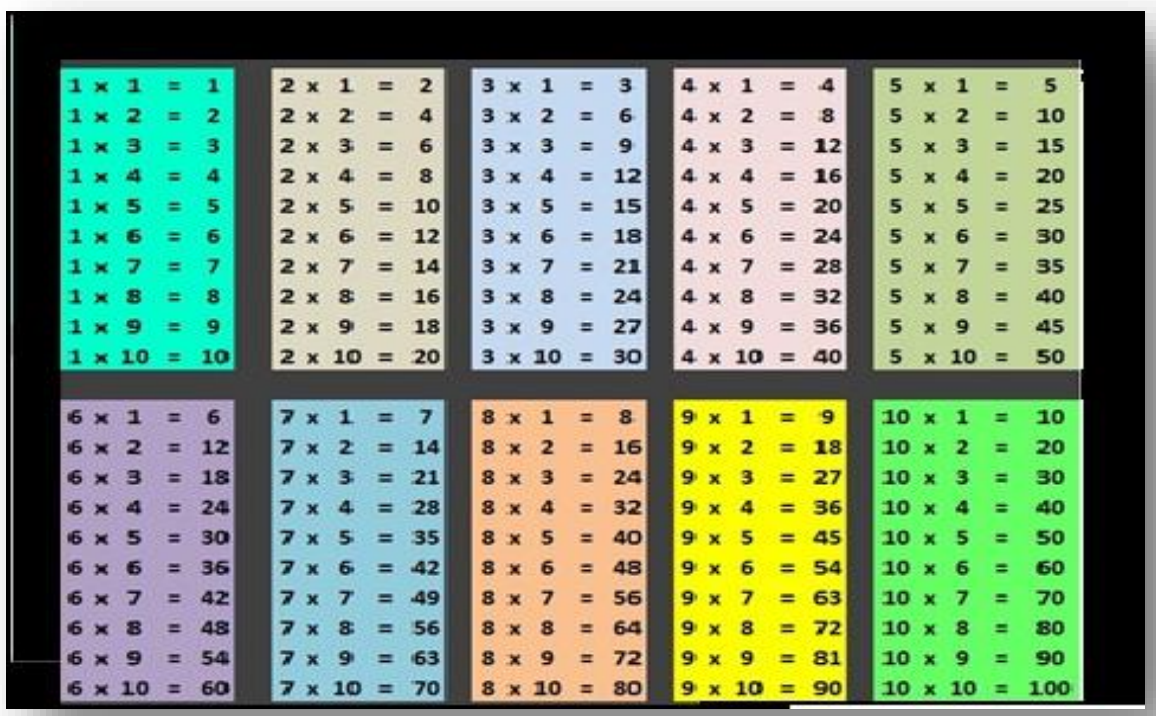

Sumber : Buku Pembelajaran Matematika Kelas II

Gambar 1.1 Perkalian Pada Umumnya

\begin{tabular}{|c|c|c|c|c|c|c|c|}
\hline \multicolumn{8}{|l|}{$2 \times 2=4$} \\
\hline $3 \times 2=6$ & $3 \times 3=9$ & & & & & & \\
\hline $4 \times 2=8$ & $4 \times 3=12$ & $4 \times 4=16$ & & & & & \\
\hline $5 \times 2=10$ & $5 \times 3=15$ & $5 \times 4=20$ & $5 \times 5=25$ & & & & \\
\hline $6 \times 2=12$ & $6 \times 3=18$ & $6 \times 4=24$ & $6 \times 5=30$ & $6 \times 6=36$ & & & \\
\hline $7 \times 2=14$ & $7 \times 3=21$ & $7 \times 4=28$ & $7 \times 5=35$ & $7 \times 6=42$ & $7 \times 7=49$ & & \\
\hline $8 \times 2=16$ & $8 \times 3=24$ & $8 \times 4=32$ & $8 \times 5=40$ & $8 \times 6=48$ & $8 \times 7=56$ & $8 \times 8=64$ & \\
\hline $9 \times 2=18$ & $9 \times 3=27$ & $9 \times 4=36$ & $9 \times 5=45$ & $9 \times 6=54$ & $9 \times 7=63$ & $9 \times 8=72$ & $9 \times 9=81$ \\
\hline $10 \times 2=20$ & $10 \times 3=30$ & $10 \times 4=40$ & $10 \times 5=50$ & $10 \times 6=60$ & $10 \times 7=70$ & $10 \times 8=80$ & $10 \times 9=90$ \\
\hline
\end{tabular}

Sumber :Tabel Perkalian Guru MI Al-Hasan Penelitian Tahun 2020

Gambar 1.2 Tabel perkalian dengan teori tangga dan teori jalan

Inti dari proses pembelajaran matematika pada perkalian tersebut menekankan pada angka-angka di dalam tabel yang tidak membebani anak didik. Dengan menulis perkalian dari 1-100 akan membuat anak didik merasa berat dan itu berakibat pada pola pikir anak didik bahwa mereka harus menghapal terlalu banyak. Jadi pada teori jalan disini seorang pendidik bisa memberikan jalan termudah untuk bisa memahami matematika. Dengan adanya tabel di atas anak anak tidak mengulangi angka yang sebenarnya sudah ada pada perkalian sebelumnya, misal 3x4 suda ada di perkalian nominal perkalian 3 jadi tidak perlu diulang di nominal perklaian 4, pada perkalian 4 cukup meneruskan yaitu perkalian 4x5 yang sebenarnya belum ada pada tabel sebelumnya, atau dengan kata lain setiap tabel meneruskan perkalian sebelumnya tanpa harusmengulang dengan angka yang sama. 
Kedua, Setelah membuat tabel matematika dengan teori jalan tersebut, pendidik melaksanakan evaluasi, selalu menekankan dan mengulang perkalian tersebut setiap kali ada pertemuan matematika dan mengulang ulang dalam permainan yang dipadukan dengan reward and punishment yang menjadikan kegiatan rutin sebelum dimulai pembelajaran matematika. Agar anak selalu semangat dalam melaksakan kegiatan pembelajaran matematika, dan pada inti selanjutnya pendidik memperhatikan penekanan pada perkalian yang sulit seperti 8x7, 6x9 dan 7x9 maksudnya lebih sering untuk diulang dan dihadirkan pada setiap pertemuan pada pembelajaran matematika yang dilaksanakan Di kelas II MI Al-Hasan.

Pada proses pembelajaran matematika dengan teori ini memang masih menekankan tingkat berpikir pada tahap menghafal yang kemudian difahami dengan permainan, agar anak didik memiliki dasar yang kokoh dalam memahami matematika yaitu dengan mencari jalan termudah dan terbaik sesuai dengan cara belajar anak didik. Berdasarkan hasil wawancara dengan kepala sekolah, yaitu pak Hasbulloh ${ }^{3}$, pembelajaran matematika dengan menggunakan strategi teori tangga dan teori jalan pada kelas II MI AlHasan berjalan efektif. Anak anak bisa lebih memahami matematika dengan baik, menurut beliau semenjak matematika dipegang oleh bapak hanip yang mengajar matematika dari kelas I-VI, prestasi matematika pada nilai hasil Ujian Nasional MI Al-Hasan Meningkat. ${ }^{4}$

Wawancara yang dilakukan dengan salah satu orang tua wali yaitu ibu Siti Nur Faiqoh yang mengatakan anaknya semakin rajin belajar semenjak melaksakan pembelajaran matematika dengan menggunakan teori tangga dan teori jalan. ${ }^{5}$ Dari beberapa point yang sudah dikaji, menggambarkan bahwa pembelajaran matematika yang diusahakan dengan kreativitas, konsisten dan juga semangat pendidik akan menghasilkan pembelajaran yang efektif dan efisien.

Pelaksanaan pembelajaran berdasarkan analisis faktor-faktor yang mempengaruhi terhadap pendidikan menurut Ibnu Miskawaih ada dua faktor. Pertama, faktor dari dalam yang mearupakan fitrah bawaan manusia sejak lahir. Kedua, faktor dari luar yang dalam hal ini berarti lingkungan. Hal ini meliputi: pelatihan, pembiasaan yang merupakan pembentukan dari pendidikan. Akan tetapi, dari kedua faktor di atas tersebut yang paling berpengaruh adalah faktor dari luar atau lingkungan, termasuk pendidikan(Miftahudin, 2019).

Berdasarkan pada pengaruh tersebut, pendidik matematika di kelas II MI Al-Hasan Mulyadadi Cipari berusaha menciptakan strategi pembelajaran khususnya mata pelajaran matematika agar menciptakan suatu kebiasaan positif, yang menunjukan bahwa pembelajaran matematika yang diusahakan dengan kreativitas, konsisten dan juga semangat pendidik akan menghasilkan pembelajaran yang efektif dan

\footnotetext{
${ }^{3}$ Wawancara dengan Bapak Hasbulloh Kepala MI Al-Hasan Mulyadadi Cipari 15 Februari 2020

${ }^{4}$ Wawancara dengan Bapak Hasbulloh Kepala MI Al-Hasan Mulyadadi Cipari 15 Februari 2020

${ }^{5}$ Wawancara dengan Siti Nur Faiqoh, Orang Tua Siswa Kelas II MI Al-Hasan Mulyadadi, 16 Februari 2020
} 
efisien. Perlu diketahui pada proses pembelajaran matematika, pendidik juga selalu menerapkan pola kejujuran, dalam mengerjakan soal evaluasi tidak boleh curang karena prinsip ketika membiarkan curang sekali saja dengan sengaja maka akan tumbuh generasi curang/ tidak jujur, contohnya membiarkan anak didik menyontek dan melaksanakan pembelajaran tanpa perencanaan dan tujuan yang jelas termasuk perbuatan dzalim. Hal itu semata mata karena manusia butuh keseimbangan hidup antara, agama, pendidikan, sosial dan ekonomi. seperti yang dikutip Prinsip keseimbangan mengajarkan manusia tentang bagaimana meyakini segala sesuatu yang diciptakan Allah SWT dalam keadaan seimbang dan serasi. Hal ini dapat difahami dari Al-Quran yang telah menjelaskan bahwa:

Kamu sekali-kali tidak melibat pada ciptaan Tuban Yang Maha Pemurah sesuatu yang tidak seimbang. Maka lihatlah berulang-ulang, adakah kamu libat sesuatu yang tidak seimbang? (QS. AlMulk Ayat 3).

Prinsip inilah yang menuntut manusia bukan saja hidup seimbang, serasi dan selaras dengan dirinya sendiri, tetapi juga menuntun manusia untuk mengimplementasikan ketiga aspek tersebut dalam kehidupan sehari-hari(Ahyani \& Nurhasanah, 2020).

Kemampuan keterampilan dasar dalam dunia Pendidikan, yang pada intinya ini adalah tugas seorang Pendidik yang notabene bahwa tujuan utama dari Pendidikan Multikultural juga mempengaruhi dalam rangka memfasilitasi pembelajaran untuk melatih kemampuan ketrampilan dasar dari Siswa/Peserta Didik yang berbeda secara etnis. Pendidikan Multikultural dapat berfungsi memperbaiki penguasaan membaca, menulis dan ketrampilan matematika; materi pelajaran; dan ketrampilan proses intelektual seperti pemecahan masalah, berpikir kritis, dan pemecahan konflik dengan memberi materi dan teknik yang lebih bermakna untuk kehidupan dan kerangka berpikir dari siswa yang berbeda secara etnis(Permana \& Ahyani, 2020). 


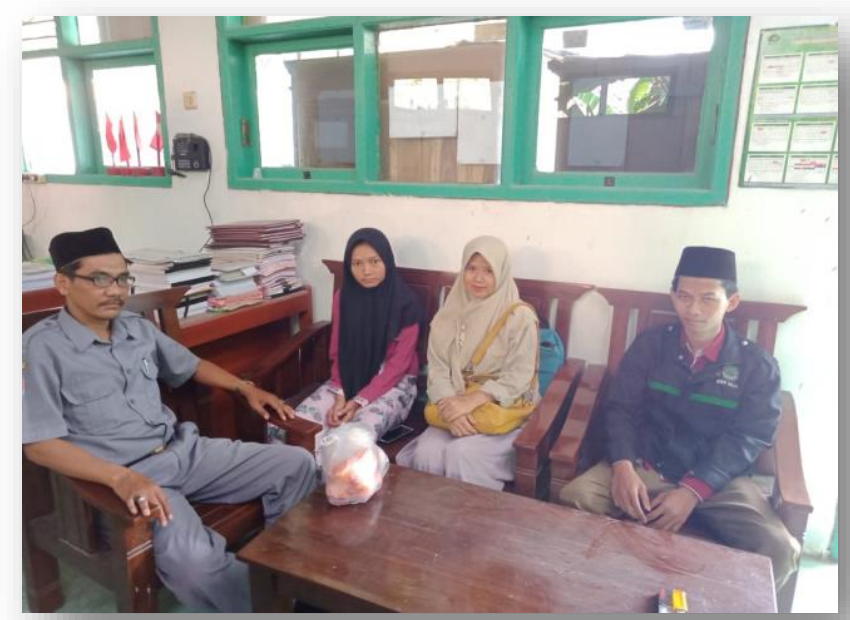

Sumber : Dokumentasi Penelitian, 2020

Gambar 1.5 Pelaksanaan Wawancara dengan Kepala Sekolah (Bapak Hasbulloh) di MI Al-Hasan Mulyadadi Cipari

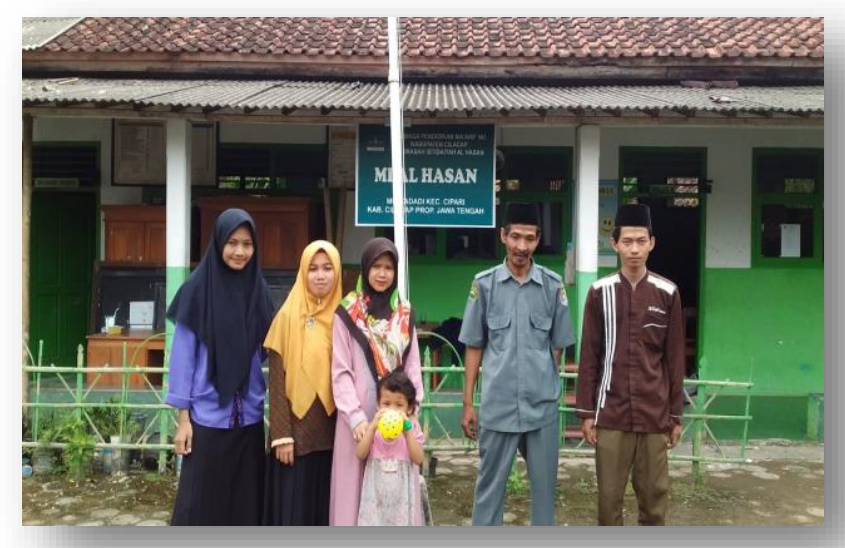

Sumber : Dokumentasi Penelitian, 2020

Gambar 1.6 Bukti pelaksanaan penelitian

di MI Al-Hasan Mulyadadi Cipari 15 Februari - 3 Maret 2020

\section{SIMPULAN}

Implementasi teori tangga dan teori jalan dalam pembelajaran matematika pada materi perkalian kelas II MI Al-Hasan Mulyadadi Cipari sebagai berikut: Strategi yang menekankan pada proses jalannya pemahaman seorang anak didik untuk belajar lebih bermakna, mengikuti perkembangan kognitif anak didik, yang kemudian dicarikan jalan termudah dalam memahami materi perkalian dalam matematika MI.

Pembelajaran matematika dengan menggunakan teori tangga dan teori jalan bisa lebih efektif dalam memberikan pemehaman penalaran anak didik kelas II MI Al-Hasan Mulyadadi Cipari pada materi perkalian. 


\section{DAFTAR PUSTAKA}

\section{Book}

Amir, Z., \& Risnawati. (2016). Psikologi Pembelajaran Matematika. Yogyakarta: Aswaja Presindo.

Fajriah, N., \& Triawati, D. (2008). Cerdas Berhitung Matematika 3,. tt: Pusat Perbukuan Departemen Pendidikan Nasional.

Hudojo, H. (2003). Mengajar Belajar Matematika. Jakarta: Proyek pengembangan lembaga pendidikan tenaga kependidikan dirjen dikti.

Suparno, P. (1997). Filsafat Konstruktivisme dalam Pendidikan. Yogyakarta: Kanisius.

\section{Jurnal Online}

Ahyani, H., \& Nurhasanah, E. (2020). Peran Strategi Politik Islam terhadap Perekonomian di Indonesia. Mutawasith Jurnal Hukum Islam, 23. 18-43. P-ISSN 2722-2764

'Azizah, M. (2018, Juni). Application of All in One System Method in Arabic Learning at MI Al-Falahiyah Mlangi, Nogotirto Gamping Sleman Yogyakarta. Thoriqotuna Jurnal Pendidikan Islam, 168. 163-175.

Dwirahayu, G., \& Nursida. (2016). Mengembangkan Pembelajaran Matematika Dengan Menggunakan. Matematika dan Pendidikan Matematika, 127. E-ISSN : 2541-2906

Muhammad, A. F. (2017). Berfikir profetik dalam Pembelajaran Matematika SD/MI. Al-Bidayah Jurnal Pendidikan Dasar Islam, 12. ISSN (Print) 2085-0034 ISSN (Online) 2549-3388

Permana, D., \& Ahyani, H. (2020). Implementasi Pendidikan Islam dan Pendidikan Multikultural pada Peserta Didik. Tawadhu, 1001.995-1006.

\section{Jurnal Cetak}

Mahardika, R. (2019). Hubungan Kinerja Guru Terhadap Motivasi Belajar Siswa Kelas X, di SMK NU Langensari Kota Banjar. Nahdatul Fikr, 20.

Miftahudin. (2019). Pendidikan Akhlak dalam Pandangan Ibnu Miskawih. Nahdlatul Fikr, 11.

Laporan Wawancara

Hanipudin. (2020, 15 Februari). Personal Interview

Hasbulloh. (2020, 15 Februari). Personal Interview

Faiqoh, S. (2020, 16 Februari). Personal Interview 